\title{
Structure dynamics of a fish community over ten years of formation in the reservoir of the hydroelectric power plant in upper Uruguay River
}

\author{
G. Schork ${ }^{*}$ and E. Zaniboni-Filho ${ }^{b}$ \\ a Laboratório de Biologia e Cultivo de Peixes de Agua Doce - LAPAD, Programa de Pós-graduação em Aquicultura, \\ Centro de Ciências Agrárias - CCA, Universidade Federal de Santa Catarina - UFSC, Rodovia 406, 3532 , \\ Armação, CEP 88066-000, Florianópolis, SC, Brazil \\ bPrograma de Pós-graduação em Aquicultura, Departamento de Aquicultura, Centro de Ciências Agrárias - CCA, \\ Universidade Federal de Santa Catarina - UFSC, Rodovia Admar Gonzaga, 1346, CEP 88034-001, Florianópolis, SC, Brazil \\ *e-mail: gianschork@gmail.com
}

Received: October 16, 2015 - Accepted: June 11, 2016 - Distributed: November 31, 2017

(With 6 figures)

\begin{abstract}
The objective of this study was to evaluate the structure of the fish assemblage in the ten years following the closing of the lake of the Itá Hydroelectric Power Plant. Seasonal collections were conducted from 2001 to 2010. During this period, 44,834 fish were captured, totaling 3,818.01 kg, among 8 orders, 24 families and 84 species. In general, profound changes were not observed in the fish assemblage in the ten years after the formation of the Itá lake. Few species changed in dominance over time, while many were rare in the environment. The ichthyofauna in the reservoir was dominated by small and medium size opportunist species that conduct short or no migratory movements. Among the most abundant, six species were responsible for more than $50 \%$ of the numeric representation: Steindachnerina brevipinna, Astyanax fasciatus, Apareiodon affinis, Hypostomus isbrueckeri, Iheringichthys labrosus and Loricariichthys anus. The increase in the representation of the later species stood out. The biomass was dominated by Steindachneridion scriptum, Prochilodus lineatus, I. laborsus, Schizodon nasutus, Hoplias malabaricus, Acestrorhynchus pantaneiro, Hoplias lacerdae, H. isbrueckeri and L. anus. Despite the presence of large migrators in the region of the reservoir, their vulnerability was revealed by the low numeric abundance and accidental capture. The k-dominance curve of numerical abundance and biomass indicates a moderately disturbed community, in which the representation of small species was also important to the amounts of biomass.
\end{abstract}

Keywords: dam, ichthyofauna, southern Brazil, temporal variation, Itá.

\section{Dinâmica da estrutura da comunidade íctica ao longo de dez anos da formação do reservatório da usina hidrelétrica no Alto Rio Uruguai}

\begin{abstract}
Resumo
O objetivo deste trabalho foi avaliar a estrutura da assembleia de peixes nos dez anos seguintes ao fechamento do lago da Usina Hidrelétrica de Itá. Para isto, foram realizadas coletas com periodicidade sazonal no período compreendido entre 2001 e 2010. Durante o período de estudo, foram capturados 44834 peixes, totalizando $3818,01 \mathrm{~kg}$, distribuídos em 8 ordens, 24 famílias e 84 espécies. De uma forma geral, a assembleia de peixes não mostrou alterações profundas nos dez anos após a formação do lago de Itá. Poucas espécies alternam-se na dominância ao longo do tempo, enquanto muitas mostraram-se como raras no ambiente. A ictiofauna do reservatório foi dominada por espécies oportunistas, de pequeno e médio porte e que realizam curtos ou nenhum movimento migratório. Entre as mais abundantes, seis espécies foram responsáveis por mais de 50\% da representatividade numérica, sendo elas: Steindachnerina brevipinna, Astyanax fasciatus, Apareiodon affinis, Hypostomus isbrueckeri, Iheringichthys labrosus e Loricariichthys anus. Destaque para aumento da representatividade deste último. Já para a biomassa, destacaram-se: Steindachneridion scriptum, Prochilodus lineatus, I. labrosus, Schizodon nasutus, Hoplia smalabaricus, Acestrorhynchus pantaneiro, Hoplias lacerdae, H. isbrueckeri e L. anus. Apesar da presença de grandes migradores na área do reservatório, sua vulnerabilidade ficou evidenciada pelas baixas abundâncias numéricas e capturas acidentais. A curva de k-dominância de abundância numérica e de biomassa indicou uma comunidade moderadamente perturbada, na qual a representatividade de espécies de pequeno porte foi importante também para os valores de biomassa.
\end{abstract}

Palavras-chave: barragem, ictiofauna, sul do Brasil, variação temporal, Itá. 


\section{Introduction}

Electrical energy production in Brazil still depends essentially on hydroelectricity, which is responsible for approximately $65 \%$ of the national energy supply (Brasil, 2015). Thus, the construction of dams for hydroelectric energy generation is now among the main anthropogenic impacts on Brazilian watersheds, substantially modifying most of the country's large rivers. The interruption in the natural flow of the rivers damages their hydrological connectivity (Vannote et al., 1980), causing a series of changes so intense that a new ecosystem is formed (Baxter, 1977).

This substitution of lotic waters for lentic waters causes changes in the water retention time, in the size of the sediments and nutrients and in various limnological variables (Souza-Filho, 2009; Ribeiro-Filho et al., 2011). Therefore, implications for the biodiversity of the location altered are felt at different trophic levels, even on the fish assemblage (Jorgensen et al., 2013). The main changes described for the ichthyofauna in reservoirs include the proliferation of opportunist species and the decline of species with greater ecological demands (Agostinho et al., 1999).

Migratory species are particularly affected by the interruption of their migratory routes and the decrease in the number of habitats needed to complete their life cycle (Agostinho et al., 2003). Normally, the reproduction habitats are located in the upper portions of large rivers and affluents (Vazzoler et al., 1997) and for this reason, the dams form obstacles to the migratory routes of adults upriver and to the drift of fish eggs and larva. These impacts are accentuated in so-called cascading reservoirs which, arranged in sequence, form systems of extreme complexity (Tundisi and Straskraba, 1999) and make even more rare the remaining lotic stretches that are so necessary for the migratory species.

The Upper Uruguay River Basin in Brazil has received a growing number of hydroelectric projects. Of a total of six large power plants planned for the region, five have already been built, all installed to form a cascading system. The Itá hydroelectric dam is located on the Uruguay River, the main river in the watershed, formed by the confluence of the Pelotas and Canoas Rivers. On this portion, the river flows over a typically hilly terrain with stretches of waterfalls and the presence of a narrow channel. Thus, unlike other rivers in the Prata watershed, the regions marked by the absence of floodplains and marginal lakes, and by tributaries that are not very long.

Despite the various recent studies conducted at Brazilian reservoirs (Petesse and Petrere-Junior, 2012; Araujo et al., 2013; Novaes et al., 2014; Sanches et al., 2016; Montenegro et al., 2012), there are few researchers that have had the opportunity to study the ichthyofauna through scientific monitoring over a long period. Only continuous accompaniment of the environment can construct a long-term investigation that is capable of providing responses that can often not be observed in another manner (Elliott, 1990; Cody, 1996) and assist in possible mitigating actions. Thus, this study sought to evaluate the composition and structure of the ichthyofauna in the Itá reservoir. Based on this characterization, it studied possible changes in the fish assemblage over the ten years following the formation of the lake.

\section{Material and Methods}

The Itá hydroelectric power plant is located between the municipalities of Itá (SC) and Aratiba (RS) and was the first large power plant built on the upper portion of the Uruguay River (Zaniboni-Filho et al., 2008), initiating operations in March 2000. The reservoir formed by the project has a total area of $141 \mathrm{sq} . \mathrm{km}$ and average depth of 36 meters with a maximum depth of $125 \mathrm{~m}$. With a perimeter of approximately $800 \mathrm{~km}$, it encompasses eight municipalities; four in Rio Grande do Sul State and four in Santa Catarina. Composing a cascading system of dams above the Itá hydroelectric power plant, there is the Machadinho hydroelectric dam, built in the bed of the Uruguay River, the Barra Grande hydroelectric power plant on the Pelotas River and the Campos Novos hydroelectric power plant built on the Canoas River.

The information was obtained at the Itá reservoir through seasonal collections that began in January 2001 and continued until December 2010. A total of 40 collections were conducted at six sample points distributed among the different environments formed by the reservoir: lentic, lotic and transition (Figure 1).

The fishing equipment used in the collection included: gillnets with spaces of $1.5 ; 2.0 ; 2.5$ and $3.0 \mathrm{~cm}$ between the cords - all $1.6 \mathrm{~m}$ tall with length varying from 10 to $30 \mathrm{~m}$ - and gillnets with $8 \mathrm{~cm}$ spaces, 8 meters tall and 60 to $120 \mathrm{~m}$ long. In addition, trammel nets with 3.0 to $5.0 \mathrm{~cm}$ gaps, $1.8 \mathrm{~m}$ tall and 15 to $40 \mathrm{~m}$ long. All of the nets were always placed in the environment at nightfall and collected in the morning, after remaining in the water for approximately 12 hours. The same procedure was used for a long-line (with 100 hooks). At each point, three casts were also made using seine nets (mesh with $8 \mathrm{~mm}$ gaps and $7 \mathrm{~m}$ long) and ten casts of a throw net (mesh of $8 \mathrm{~mm}$ and $13.5 \mathrm{~m}$ in diameter), always during the day.

After harvesting fish, specimens were identified up to species levels according to a taxonomic key. Measurements of total weight $(\mathrm{g})$ and total length $(\mathrm{cm})$ were taken in the field. The specimens were fixed in $10 \%$ formalin solution and then placed in containers with ethanol at $70 \%$. Specimens that could not be identified in the field were transported to the Ichthyology Laboratory of Londrina State University in the state of Paraná or to the Museum of Science and Technology of Pontifícia Universidade Católica of Rio Grande do Sul (PUC), where they were identified.

Assemblage structure was evaluated by richness index (number of species), total biomass ( $\mathrm{g}$ ), total number of individuals, Shannon-Wiener index (H') (Krebs, 1998), equitability (E) (Pielou, 1966) and dominance (Simpson, 1949). The constancy among species was calculated according to Dajoz (1973). 


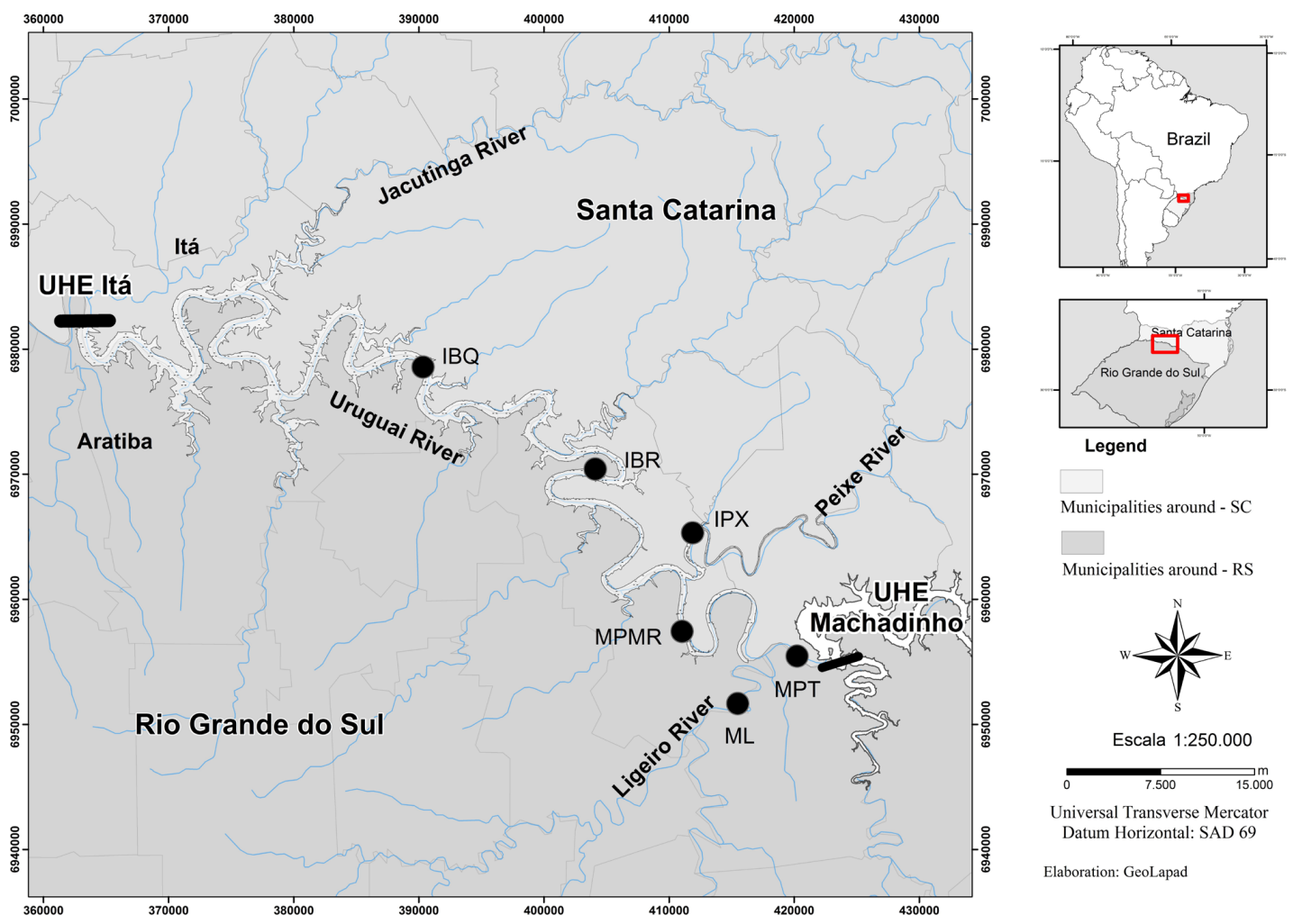

Figure 1. Location of the Itá hydroelectric plant on the Uruguay River between Santa Catarina and Rio Grande do Sul states.

To evaluate the differences between the various samples, variance analyses were conducted (ANOVA with repeated measures). Before this, the data were tested for normality (Shapiro-Wilk test) and homoscedasticity (Levene test). To meet the presumptions, the data for biomass and dominance were transformed by $\log (\mathrm{x}+1)$. When significant differences were present $(p<0.01)$, the Tukey test was applied to identify the level of difference of the factor. When the presumptions for normality and homoscedasticity were not achieved, the corresponding non-parametric test was applied (Friedman ANOVA).

The non-metric ordination method - NMDS - was used to verify temporal variations in the composition and numeric abundance of the ichthyic assemblage (Clarke and Warwick, 2001). According to these authors, the values for the number of individuals were transformed in $\log (x+1)$ prior to the calculation of the Bray-Curtis similarity index to approximate the contribution of the rare species to those that were very abundant in the samples.

The analysis of similarity - ANOSIM - was applied to test the null hypothesis that there are no differences in the assemblies between the years with levels of significance of $\mathrm{p}<0.01$ for 9.999 permutations. The $\mathrm{R}$ statistic allows recognizing how much the groups are separated, on an interval considered as follows: indistinguishable $(\mathrm{R}<0.25)$; minimally separable $(\mathrm{R}>0,25)$; overlapping, but clearly different $(R>0.5)$; or well separated $(R>0.75)$ (Clarke and Gorley, 2001). To determine the individual contribution of each species to the similarities found in each year similarity percentage analysis was conducted (SIMPER) using PRIMER 6 software. To indicate species with consistent contribution over the years, the cutoff was made at $80 \%$. The same software was used to determine the ABC curve (Warwick, 1986) and the W statistic (Clarke, 1990).

\section{Results}

Over the entire sampling period at the Itá reservoir, a total of 44,834 fish were caught, with a total of $3,818.01 \mathrm{~kg}$, distributed among 8 orders, 24 families and 84 species. The Characiformes order was the most abundant, representing more than $60 \%$ of the number of individuals caught, more than $50 \%$ of the biomass and approximately $40 \%$ of the species and families observed. They were followed by the Siluriformes, representing $40 \%$ of the total biomass captured and nearly $30 \%$ of the species, families and number of individuals caught. Meanwhile, the Perciformes composed approximately $10 \%$ of the families and species caught, although with a much lower participation in the number of individuals and biomass than the above-mentioned orders. The other orders combined (Atheriniformes, Cypriniformes, Cyprinodontiformes, Gymnotiformesand Synbranchiformes) were responsible for $9 \%$ of the families, $25 \%$ of the species, $4 \%$ of the biomass caught and only $1 \%$ of the number of individuals caught during the sample period. 
Because of their numeric abundance, six species totaled more than $50 \%$ of those caught, all of which are considered sedentary or short-distance migrators: the biru Steindachnerina brevipinna (15.9\%), the lambari Astyanax fasciatus (12.1\%), the canivete Apareiodon affinis (6.5\%), the cascudos Hypostomus isbrueckeri (6.6\%) and Loricariichthys anus (5.9\%), and the mandi Iheringichthys labrosus (5.8\%). In terms of biomass, nine species were responsible for more than $50 \%$ of those caught. Among them, only the curimba Prochilodus lineatus (4.9\%) undertakes long reproductive migrations. The others are the voga Schizodon nasutus (9.2\%), the traíra $H$. malabaricus (7.9\%), the peixe-cachorro Acestrorhynchus pantaneiro (7.5\%), the suruvi Steindachneridion scriptum $(6,2 \%)$, the trairão $H$. lacerdae (5.4\%) and the previously mentioned I. labrosus $(4.6 \%), H$. isbrueckeri $(6,9 \%)$ and L. anus $(4,9 \%)$ (Table 1$)$.
Nineteen species were constant in the catches, present in more than $50 \%$ of the collections, and only eight species were classified as accessories. The highest number of species was those considered accidental (57), the category in which all the long distance migratory were classified (Table 1).

Three exotic species were found, the tilapia Oreochromis niloticus and the carp Ctenopharingodon idellus and C. carpio. For the two species of piranhas found in the reservoir, Pygocentrus nattereri and Serrasalmus maculatus, the low numeric abundance of the catch remained constant throughout the period of study.

Using variance analysis (ANOVA with repeated measures), a significant difference was found $(\mathrm{p}<0.05)$ only for the amount of richness between the years of the study. There was no difference for the number of individuals, biomass, and the other indicators analyzed - dominance $(\log (x+1))$, equitability and Shannon H' (Figure 2).

Table 1. Identification number, absolute and relative abundance for the number of individuals [n and $\mathrm{n}(\%)$ ] and biomass [B and $\mathrm{B}(\%)]$ of each species, beyond the Dajoz constant for the catches in the Itá reservoir from 2001 to 2010 (Cons constant, Aces - accessory, Acid - accidental).

\begin{tabular}{|c|c|c|c|c|c|c|}
\hline \multicolumn{2}{|r|}{$\mathbf{N}^{0}$ - Identification number } & \multirow{2}{*}{$\mathbf{n}$} & \multirow{2}{*}{$\mathbf{n}(\%)$} & \multirow{2}{*}{ B } & \multirow{2}{*}{$\mathbf{B}(\%)$} & \multirow{2}{*}{ Cons } \\
\hline ID N ${ }^{0}$ & Scientific name & & & & & \\
\hline & ATHERINIFORMES & 94 & 0.21 & 2.28 & 0.06 & \\
\hline & Atherinopsidae & 94 & 0.21 & 2.28 & 0.06 & \\
\hline \multirow[t]{3}{*}{56} & Odontesthes perugiae Evermann \& Kendall 1906 & 94 & 0.21 & 2.28 & 0.06 & Acid \\
\hline & CHARACIFORMES & 30208 & 67.40 & $2,108.84$ & 55.24 & \\
\hline & Acestrorhynchidae & 2437 & 5.44 & 287.38 & 7.53 & \\
\hline \multirow[t]{2}{*}{3} & Acestrorhynchus pantaneiro Menezes 1992 & 2437 & 5.44 & 287.38 & 7.53 & Cons \\
\hline & Anostomidae & 2255 & 5.03 & 401.79 & 10.52 & \\
\hline 39 & Leporinus amae Godoy 1980 & 45 & 0.10 & 1.46 & 0.04 & Acid \\
\hline 75 & Leporinus macrocephalus Garavello \& Britski 1988 & 1 & 0.00 & 0.14 & 0.00 & Acid \\
\hline 55 & Leporinus obtusidens (Valenciennes 1837) & 22 & 0.05 & 47.24 & 1.24 & Acid \\
\hline 76 & Leporinus striatus Kner 1858 & 2 & 0.00 & 0.02 & 0.00 & Acid \\
\hline \multirow[t]{2}{*}{7} & Schizodon nasutus Kner 1858 & 2185 & 4.87 & 352.93 & 9.24 & Cons \\
\hline & Bryconidae & 24 & 0.05 & $\mathbf{5 7 . 1 2}$ & 1.50 & \\
\hline 65 & Brycon orbignyanus (Valenciennes 1850) & 10 & 0.02 & 6.37 & 0.17 & Acid \\
\hline \multirow[t]{2}{*}{41} & Salminus brasiliensis (Cuvier 1816) & 14 & 0.03 & 50.75 & 1.33 & Acid \\
\hline & Characidae & 14025 & 31.29 & 397.81 & 10.42 & \\
\hline 44 & Astyanax eigenmanniorum (Cope 1894) & 36 & 0.08 & 0.65 & 0.02 & Acid \\
\hline 5 & Astyanax fasciatus (Cuvier 1819) & 5431 & 12.11 & 86.08 & 2.25 & Cons \\
\hline 6 & Astyanax scabripinnis (Jenyns 1842) & 1426 & 3.18 & 27.48 & 0.72 & Cons \\
\hline 8 & Astyanax jacuhiensis (Cope 1894) & 2497 & 5.57 & 33.95 & 0.89 & Cons \\
\hline 58 & Astyanax sp 3 & 88 & 0.20 & 1.78 & 0.05 & Acid \\
\hline 16 & Bryconamericus iheringii (Boulenger 1887) & 680 & 1.52 & 0.72 & 0.02 & Aces \\
\hline 4 & Bryconamericus stramineus Eigenmann 1908 & 1320 & 2.94 & 1.3 & 0.03 & Aces \\
\hline 66 & Charax leticiae Lucena 1987 & 1 & 0.00 & 0.01 & 0.00 & Acid \\
\hline 72 & Cynopotamus kincaidi (Schultz 1950) & 91 & 0.20 & 8.07 & 0.21 & Acid \\
\hline 25 & Galeocharax humeralis (Valenciennes 1834) & 1250 & 2.79 & 110.49 & 2.89 & Cons \\
\hline 60 & Oligosarcus brevioris Menezes 1987 & 16 & 0.04 & 1.6 & 0.04 & Acid \\
\hline 10 & Oligosarcus jenynsii (Günther 1864) & 1187 & 2.65 & 125.5 & 3.29 & Cons \\
\hline \multirow[t]{2}{*}{82} & Roeboides sp. & 2 & 0.00 & 0.18 & 0.00 & Acid \\
\hline & Crenuchidae & 16 & 0.04 & 0.02 & $\mathbf{0 . 0 0}$ & \\
\hline 37 & Characidium zebra Eigenmann 1909 & 16 & 0.04 & 0.02 & 0.00 & Acid \\
\hline
\end{tabular}


Table 1. Continued...

\begin{tabular}{|c|c|c|c|c|c|c|}
\hline \multicolumn{2}{|r|}{$\mathbf{N}^{0}$ - Identification number } & \multirow{2}{*}{$\mathbf{n}$} & \multirow{2}{*}{$\mathbf{n}(\%)$} & \multirow{2}{*}{ B } & \multirow{2}{*}{$\mathbf{B}(\%)$} & \multirow{2}{*}{ Cons } \\
\hline ID $\mathbf{N}^{0}$ & Scientific name & & & & & \\
\hline & Curimatidae & 7247 & 16.17 & 142.63 & 3.74 & \\
\hline 73 & Cyphocharax sp & 4 & 0.01 & 0.19 & 0.00 & Acid \\
\hline 83 & Steindachnerina biornata (Braga \& Azpelicueta 1987) & 114 & 0.25 & 2.43 & 0.06 & Acid \\
\hline \multirow[t]{2}{*}{1} & $\begin{array}{l}\text { Steindachnerina brevipinna (Eigenmann \& Eigenmann } \\
\text { 1889) }\end{array}$ & 7129 & 15.90 & 140.01 & 3.67 & Cons \\
\hline & Erythrinidae & 712 & 1.59 & 506.89 & 13.28 & \\
\hline 12 & Hoplias lacerdae Miranda Ribeiro 1908 & 295 & 0.66 & 204.09 & 5.35 & Cons \\
\hline \multirow[t]{2}{*}{13} & Hoplias malabaricus (Bloch 1794) & 417 & 0.93 & 302.8 & 7.93 & Cons \\
\hline & Paradontidae & 2891 & 6.45 & 24.8 & 0.65 & \\
\hline \multirow[t]{2}{*}{12} & Apareiodon affinis (Steindachner 1879) & 2891 & 6.45 & 24.8 & 0.65 & Cons \\
\hline & Prochilodontidae & 90 & 0.20 & 188.83 & 4.95 & \\
\hline \multirow[t]{2}{*}{46} & Prochilodus lineatus (Valenciennes 1837) & 90 & 0.20 & 188.83 & 4.95 & Acid \\
\hline & Serrasalmidae & 511 & 1.14 & 101.57 & 2.66 & \\
\hline 79 & Piaractus mesopotamicus (Holmberg 1887) & 1 & 0.00 & 2.01 & 0.05 & Acid \\
\hline 48 & Pygocentrus nattereri Kner 1858 & 103 & 0.23 & 26.85 & 0.70 & Acid \\
\hline \multirow{3}{*}{24} & Serrasalmus maculatus Kner 1858 & 407 & 0.91 & 72.71 & 1.90 & Cons \\
\hline & CYPRINIFORMES & 64 & 0.14 & 111.47 & 2.92 & \\
\hline & Cyprinidae & 64 & 0.14 & 111.47 & 2.92 & \\
\hline 71 & Ctenopharyngodon idella (Valenciennes 1844) & 2 & 0.00 & 6.8 & 0.18 & Acid \\
\hline \multirow[t]{3}{*}{30} & Cyprinus carpio Linnaeus 1758 & 62 & 0.14 & 104.67 & 2.74 & Acid \\
\hline & CYPRINODONTIFORMES & 1 & $\mathbf{0 . 0 0}$ & $\mathbf{0 . 0 0}$ & $\mathbf{0 . 0 0}$ & \\
\hline & Poeciliidae & 1 & $\mathbf{0 . 0 0}$ & $\mathbf{0}$ & $\mathbf{0 . 0 0}$ & \\
\hline \multirow[t]{3}{*}{78} & Phalloceros caudimaculatus (Hensel 1868) & 1 & 0.00 & 0 & 0.00 & Acid \\
\hline & GYMNOTIFORMES & 220 & 0.49 & 34.96 & 0.92 & \\
\hline & Gymnotidae & 75 & 0.17 & 31.58 & 0.83 & \\
\hline 36 & Gymnotus carapo Linnaeus 1758 & 73 & 0.16 & 30.85 & 0.81 & Acid \\
\hline \multirow[t]{2}{*}{53} & Gymnotus sp & 2 & 0.00 & 0.73 & 0.02 & Acid \\
\hline & Sternopygidae & 145 & 0.32 & 3.38 & 0.09 & \\
\hline \multirow[t]{3}{*}{31} & Eigenmannia virescens (Valenciennes 1836) & 145 & 0.32 & 3.38 & 0.09 & Aces \\
\hline & PERCIFORMES & 955 & 2.13 & 29.87 & 0.78 & \\
\hline & Cichlidae & 942 & 2.10 & 29.44 & 0.77 & \\
\hline 68 & Crenicichla celidochilus Casciotta 1987 & 41 & 0.09 & 1.24 & 0.03 & Acid \\
\hline 69 & Crenicichla igara Lucena \& Kullander 1992 & 22 & 0.05 & 2.42 & 0.06 & Acid \\
\hline 45 & Crenicichla jurubi Lucena \& Kullander 1992 & 52 & 0.12 & 2.31 & 0.06 & Acid \\
\hline 52 & Crenicichla minuano Lucena \& Kullander 1992 & 42 & 0.09 & 1.25 & 0.03 & Acid \\
\hline 35 & Crenicichla missioneira Lucena \& Kullander 1992 & 69 & 0.15 & 3.25 & 0.09 & Acid \\
\hline 70 & Crenicichla tendybaguassu Lucena \& Kullander 1992 & 1 & 0.00 & 0.02 & 0.00 & Acid \\
\hline 33 & Crenicichla vittata Heckel 1840 & 171 & 0.38 & 11.36 & 0.30 & Aces \\
\hline 23 & Geophagus brasiliensis (Quoy \& Gaimard 1824) & 356 & 0.79 & 6.07 & 0.16 & Aces \\
\hline 32 & Gymnogeophagus gymnogenys (Hensel 1870) & 127 & 0.28 & 0.38 & 0.01 & Acid \\
\hline 38 & Gymnogeophagus rhabdotus (Hensel 1870) & 8 & 0.02 & 0.06 & 0.00 & Acid \\
\hline \multirow[t]{2}{*}{57} & Oreochromis niloticus (Linnaeus 1758) & 53 & 0.12 & 1.08 & 0.03 & Acid \\
\hline & Sciaenidae & 13 & 0.03 & 0.43 & 0.01 & \\
\hline \multirow[t]{3}{*}{77} & Pachyurus bonariensis Steindachner 1879 & 13 & 0.03 & 0.43 & 0.01 & Acid \\
\hline & SILURIFORMES & 13286 & 29.63 & $1,530.34$ & 40.07 & \\
\hline & Auchenipteridae & 387 & 0.86 & 22.93 & 0.60 & \\
\hline 49 & Auchenipterus sp. & 30 & 0.07 & 1.94 & 0.05 & Acid \\
\hline 61 & Trachelyopterus ceratophysus (Kner 1858) & 1 & 0.00 & 0.05 & 0.00 & Acid \\
\hline 14 & Trachelyopterus galeatus (Linnaeus 1766) & 326 & 0.73 & 19.5 & 0.51 & Aces \\
\hline 29 & Trachelyopterus teaguei (Devincenzi 1942) & 30 & 0.07 & 1.44 & 0.04 & Acid \\
\hline
\end{tabular}


Table 1. Continued...

\begin{tabular}{|c|c|c|c|c|c|c|}
\hline \multicolumn{2}{|r|}{$\mathbf{N}^{0}$ - Identification number } & \multirow{2}{*}{$\mathbf{n}$} & \multirow{2}{*}{$\mathbf{n}(\%)$} & \multirow{2}{*}{ B } & \multirow{2}{*}{$\mathbf{B}(\%)$} & \multirow{2}{*}{ Cons } \\
\hline ID $\mathbf{N}^{0}$ & Scientific name & & & & & \\
\hline & Callichthyidae & 1 & $\mathbf{0 . 0 0}$ & $\mathbf{0}$ & 0.00 & \\
\hline \multirow[t]{2}{*}{67} & Corydoras paleatus (Jenyns 1842) & 1 & 0.00 & 0 & 0.00 & Acid \\
\hline & Cetopsidae & 6 & 0.01 & 0.13 & 0.00 & \\
\hline \multirow[t]{2}{*}{42} & Cetopsis gobioides Kner 1858 & 6 & 0.01 & 0.13 & 0.00 & Acid \\
\hline & Heptapteridae & 369 & 0.82 & 127.43 & 3.33 & \\
\hline 81 & Rhamdella longiuscula Lucena \& da Silva 1991 & 17 & 0.04 & 0.59 & 0.02 & Acid \\
\hline \multirow[t]{2}{*}{18} & Rhamdia quelen (Quoy \& Gaimard 1824) & 352 & 0.79 & 126.84 & 3.32 & Cons \\
\hline & Loricariidae & 7046 & 15.72 & 750.4 & 19.65 & \\
\hline 47 & Ancistrus sp. & 5 & 0.01 & 0.06 & 0.00 & Acid \\
\hline 51 & Ancistrus taunayi Miranda Ribeiro 1918 & 3 & 0.01 & 0.09 & 0.00 & Acid \\
\hline 28 & Pogonoma obscurum Quevedo \& Reis 2002 & 282 & 0.63 & 78.43 & 2.05 & Aces \\
\hline 19 & Hemiancistrus fuliginosus Cardoso \& Malabarba 1999 & 306 & 0.68 & 14.42 & 0.38 & Acid \\
\hline 22 & Hypostomus commersoni Valenciennes 1836 & 380 & 0.85 & 93.89 & 2.46 & Cons \\
\hline 2 & Hypostomus isbrueckeri Reis, Weber \& Malabarba 1990 & 2941 & 6.56 & 263.57 & 6.90 & Cons \\
\hline 27 & Hypostomus luteus (Godoy 1980) & 112 & 0.25 & 34.42 & 0.90 & Acid \\
\hline 54 & Hypostomus regani (Ihering 1905) & 80 & 0.18 & 36.09 & 0.95 & Acid \\
\hline 34 & $\begin{array}{l}\text { Hypostomus roseopunctatus Reis, Weber \& Malabarba } \\
1990\end{array}$ & 77 & 0.17 & 17.65 & 0.46 & Acid \\
\hline 74 & Hypostomus ternetzi (Boulenger 1895) & 4 & 0.01 & 0.24 & 0.01 & Acid \\
\hline 59 & $\begin{array}{l}\text { Hypostomus uruguayensis Reis, Weber \& Malabarba } \\
1990\end{array}$ & 6 & 0.01 & 1.4 & 0.04 & Acid \\
\hline 20 & Loricariichthys anus (Valenciennes 1835) & 2645 & 5.90 & 188.65 & 4.94 & Cons \\
\hline 21 & Loricariichthys sp.m & 106 & 0.24 & 10.08 & 0.26 & Acid \\
\hline 40 & Paraloricaria vetula (Valenciennes 1835) & 64 & 0.14 & 5.68 & 0.15 & Acid \\
\hline \multirow[t]{2}{*}{63} & Rineloricaria sp. & 35 & 0.08 & 5.73 & 0.15 & Acid \\
\hline & Pimelodidae & 5476 & 12.22 & 627.87 & 16.45 & \\
\hline 9 & Iheringichthys labrosus (Lütken 1874) & 2598 & 5.80 & 177.06 & 4.64 & Cons \\
\hline 15 & Parapimelodus valenciennis (Lütken 1874) & 1779 & 3.97 & 24.61 & 0.64 & Cons \\
\hline 80 & Pimelodella laticeps Eigenmann, 1917 & 4 & 0.01 & 0.08 & 0.00 & Acid \\
\hline 26 & Pimelodus absconditus Azpelicueta 1995 & 180 & 0.40 & 10.41 & 0.27 & Aces \\
\hline 50 & Pimelodus atrobrunneus Vidal \& Lucena 1999 & 150 & 0.33 & 6.41 & 0.17 & Acid \\
\hline 11 & Pimelodus maculatus Lacepède 1803 & 668 & 1.49 & 169.93 & 4.45 & Cons \\
\hline 64 & Sorubim lima (Bloch \& Schneider 1801) & 1 & 0.00 & 1.23 & 0.03 & Acid \\
\hline \multirow[t]{2}{*}{43} & Steindachneridion scriptum(Miranda Ribeiro 1918) & 96 & 0.21 & 238.14 & 6.24 & Acid \\
\hline & Pseudopimelodidae & 1 & $\mathbf{0 . 0 0}$ & 1.58 & 0.04 & \\
\hline \multirow[t]{3}{*}{62} & Pseudopimelodus mangurus (Valenciennes 1835) & 1 & 0.00 & 1.58 & 0.04 & Acid \\
\hline & SYNBRANCHIFORMES & 1 & 0.00 & 0.12 & 0.00 & \\
\hline & Synbranchidae & 1 & 0.00 & 0.12 & 0.00 & \\
\hline 84 & Synbranchus marmoratus Bloch 1795 & 1 & 0.00 & 0.12 & 0.00 & Acid \\
\hline
\end{tabular}

Large migrators, like the piava (Leporinus obtusidens), the dourado (Salminus brasiliensis) and the piracanjuba (Brycon orbignyanus) had low numeric abundance over the years of the study. Piracanjuba only began to be caught in 2006 and no piava were caught after 2007. The curimba (Prochilodus lineatus) was the only species in this category that was caught in a similar amount throughout the years of the study (Table 2).

Analyzing the numeric abundance of the catch, some species decreased their representation in relation to the initial years of formation of the Itá lake, including the:
A. pantaneiro (3), H. isbrueckieri (2), S. brevipinna (1) and the lambaris Astyanax scabripinnis (6) and Bryconamericus stramineus (4). In contrast, A. affinis (12), L. anus (20) and the lambari Bryconamericus iheringii (16) increased their participation over time. Meanwhile the $A$. fasciatus (5) had peaks of abundance from 2006 to 2008 and the peixe-cachorro Galeocharax humeralis (25) from 2003 to 2004. For $S$. nasutus (7), the representation in the catches was constant over the years (Figure 3).

The analysis of grouping based on the data for numeric abundance shows a high similarity between the years 
$(>80 \%)$. Within this bidimensional plotting of NMDS, two groups were formed: one composed of the three initial years and another for the other years. The stress value of 0.08 indicates graphic distances in the two dimensions with excellent representation of the similarities (Figure 4).
The dissimilarity between the years, verified with the ANOSIM analysis, obtained an R-Global equal to 0.116 for levels of significance of $\mathrm{p}<0.01$ in 9999 permutations. No pairwise comparison between the subsequent years presented a significant difference $(\mathrm{p}>0.01)$. With the

Table 2. Total number of individuals of the four species of large migrators captured in the Itá reservoir from 2001-2010.

\begin{tabular}{lcccccccccc}
\hline & $\mathbf{2 0 0 1}$ & $\mathbf{2 0 0 2}$ & $\mathbf{2 0 0 3}$ & $\mathbf{2 0 0 4}$ & $\mathbf{2 0 0 5}$ & $\mathbf{2 0 0 6}$ & $\mathbf{2 0 0 7}$ & $\mathbf{2 0 0 8}$ & $\mathbf{2 0 0 9}$ & $\mathbf{2 0 1 0}$ \\
\hline B. orbignyanus & & & & & & 4 & 4 & & 1 & 1 \\
L. obtusidens & 2 & 1 & 2 & 6 & 2 & 7 & 2 & & & \\
P. lineatus & 5 & 9 & 5 & 5 & 6 & 22 & 9 & 4 & 13 & 12 \\
S. brasiliensis & 7 & 2 & & & & 3 & 1 & & 1 \\
\hline
\end{tabular}
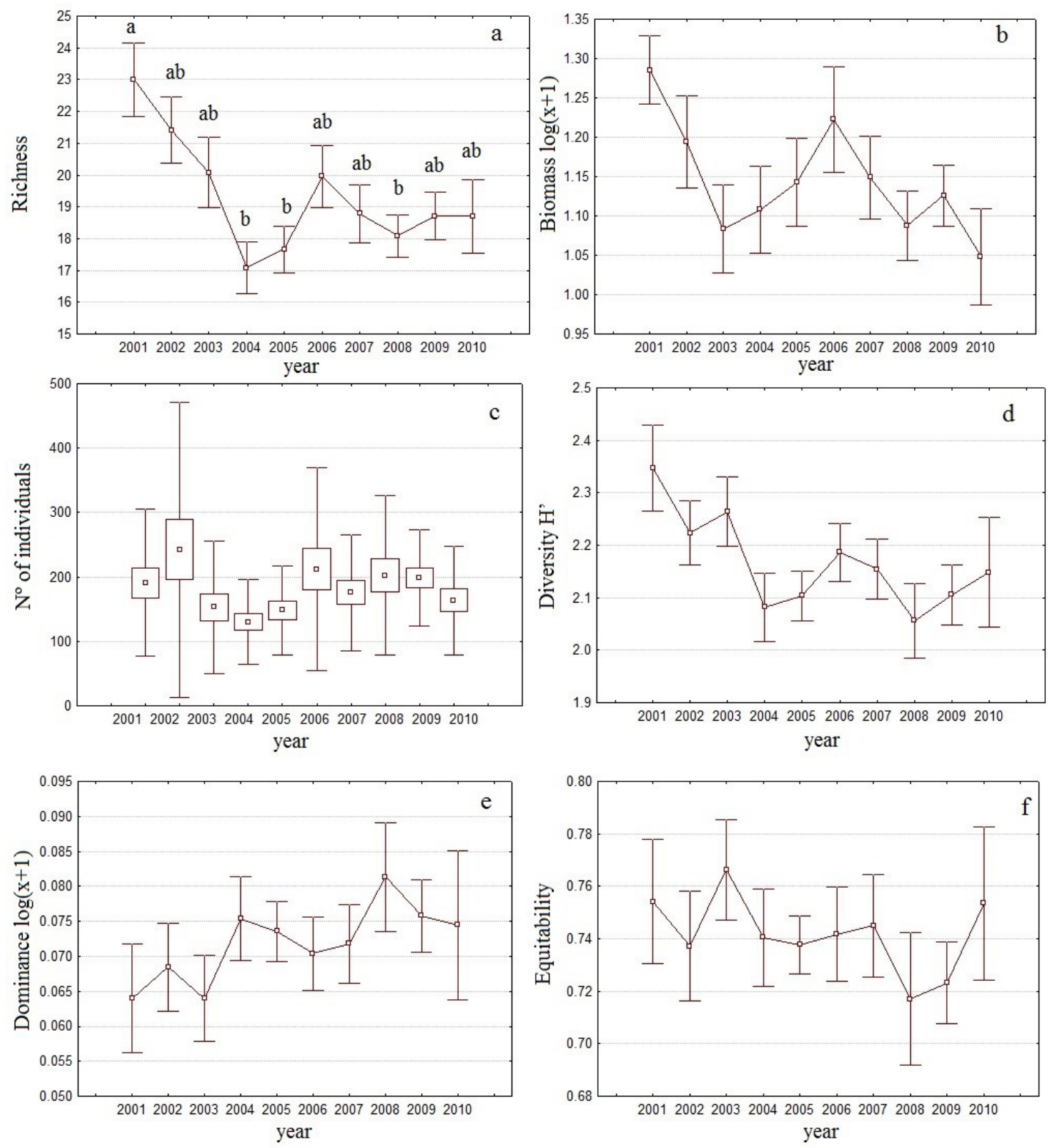

Figure 2. Statistical analysis (ANOVA with repeated measures) for (a) richness; (b) biomass $\log (\mathrm{x}+1)$; (c) $\mathrm{n}^{\mathrm{o}}$ of individuals - using the non-parametric Anova Friedman test; (d) diversity H'; (e) dominance and (f) equitability referring to the capture of fish in the Itá reservoirs between 2001 and 2010. Distinct letters in the columns indicate a significant difference $(\mathrm{p}<0.05)$. 
exception of the comparisons with the year 2001, all of the values for $\mathrm{R}$ remained below 0.3 (Figure 5).

A total of 19 species were responsible for explaining $80 \%$ of the similarity in all ten years of the study. The dissimilarity between the years of the first half of the period studied showed values a bit higher than the relationships between the final years (Table 3 ).

According to the $\mathrm{ABC}$ curve, although they are very close, the numeric abundance curves are above the biomass curves in all the years sampled after the formation of the

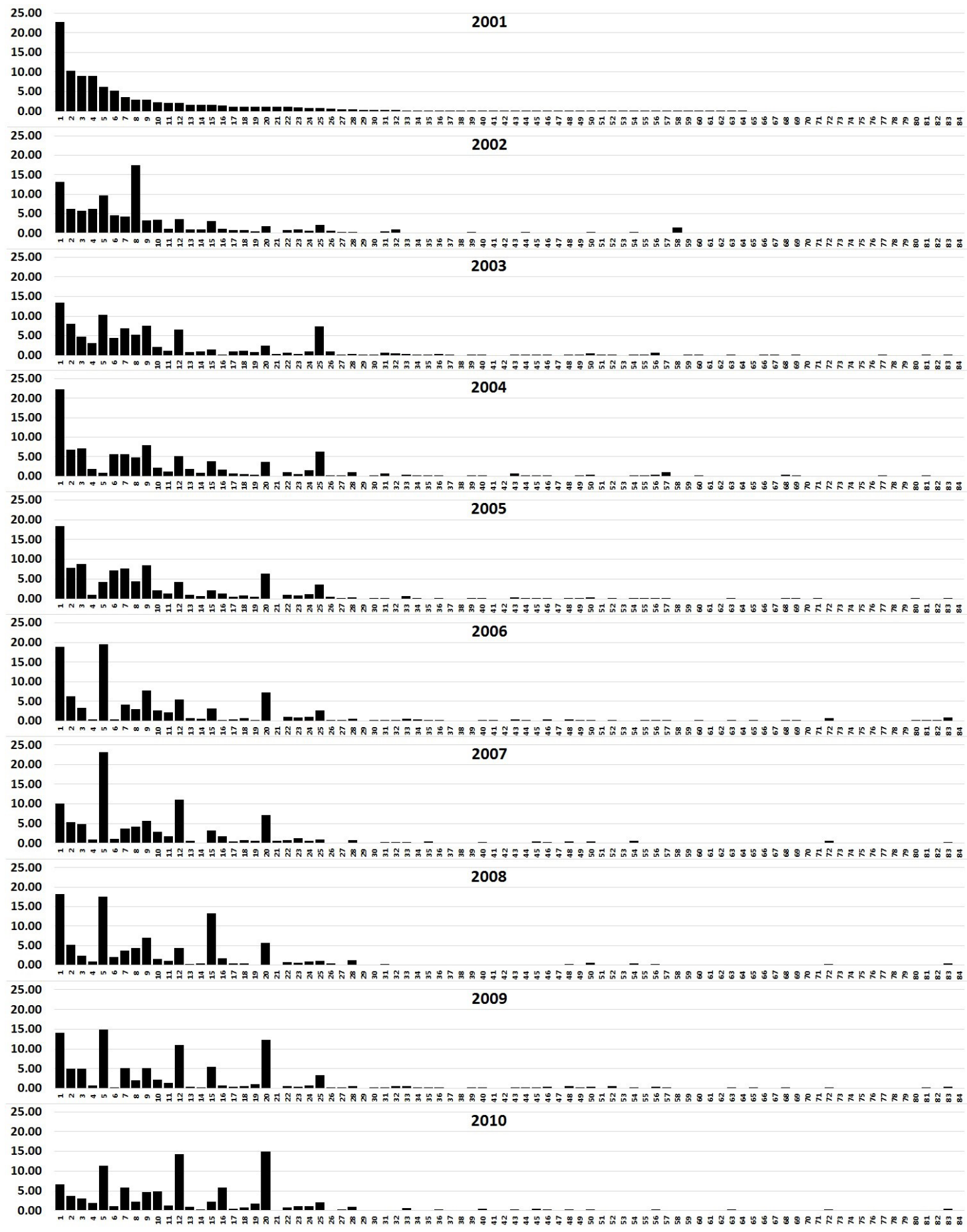

Figure 3. Representation of abundance expressed in percentage for the number of individuals of the species caught in the Itá reservoir between 2001 and 2010. The numbers on the $\mathrm{x}$ axis indicate the identification numbers of the species presented in Table 1. 
Itá reservoir. By calculating the W statistic (Clarke, 1990), values close to zero were obtained in the entire period of the study (Figure 6).

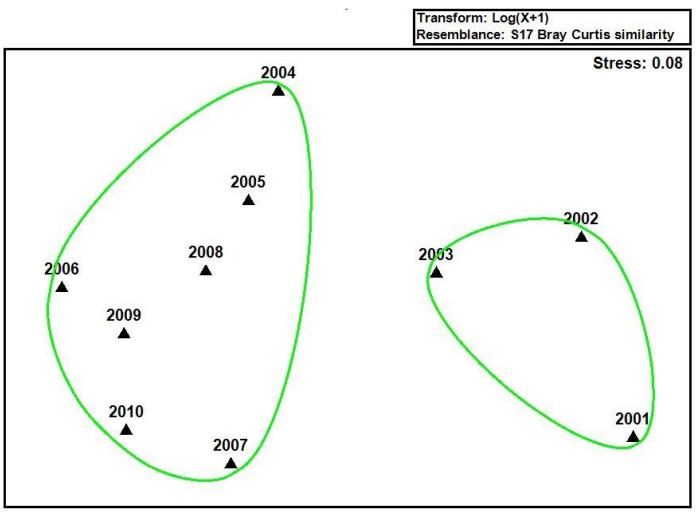

Figure 4. Analysis of ordination by the MDS method based on the data for numeric abundance of all the species caught in the Itá reservoir between 2001 and 2010. Groups delineated at the level of $84 \%$ are circled on the MDS ordination graph.

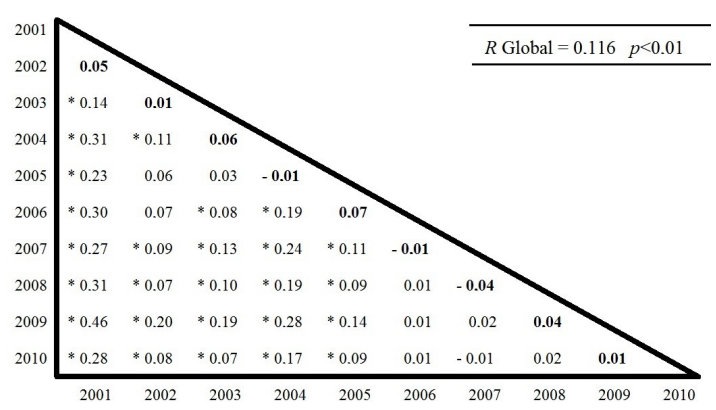

Figure 5. Values for R for the comparisons between the years obtained through the analysis of similarity (ANOSIM) based on the data for numeric abundance of all the species captured in the Itá reservoir between the years 2001 and 2010. * indicates the comparisons with significant difference $(\mathrm{p}<0.01)$.

\section{Discussion}

During the entire period of the study, 84 species were found, a number that exceeds the average of 30 species reported by Agostinho et al. (2007) for 75 Brazilian reservoirs and that approaches the 98 species described previously for the Upper Uruguay River region (Zaniboni-Filho et al., 2004). The highest value of wealth found in 2001 certainly reflects the behavior normally described at the time following implantation of reservoirs, when we have the addition of new habitats and the consequent establishment of new species (Agostinho et al., 2008). The other indicators analyzed - diversity, dominance, equitability - and number of individuals and biomass did not reveal significant changes in the ichthyofauna during the years studied.

In general, there were no profound changes in the fish assemblage in the ten years after the formation of the Itá lake. The analysis of the grouping indicates a gradual change in the assemblage, which weakly distinguishes the three initial years from the others. The ANOSIM results clearly demonstrate that the changes took place in a highly tenuous manner, not leading to differences in comparisons between the subsequent years. Despite the differences found between the initial and final years, the values for $\mathrm{R}$ below 0.25 in the majority of the relations indicate groups that are very close over time. This tendency is accentuated in the final five years, when the dissimilarities found in the pairwise comparison become smaller, showing an ichthyofauna that is even more similar in the final period of study.

Only 19 species were responsible for explaining $80 \%$ of the similarity for all the years of study, showing that despite the high value of richness many species are rare in the environment. For this reason, in terms of this study, caution is necessary when evaluating the changes in ichthyofauna solely from the perspective of statistical analyses. In addition to observing the individual variations in the representation of the most abundant species over time, it is also necessary to pay attention to the evidently vulnerable species, such as the large migrators.

Only $22.62 \%$ of the species were classified as constant in the catches. This classification only included sedentary species or those that realize short movements for reproduction. Among them are the pintado Pimelodus maculatus and
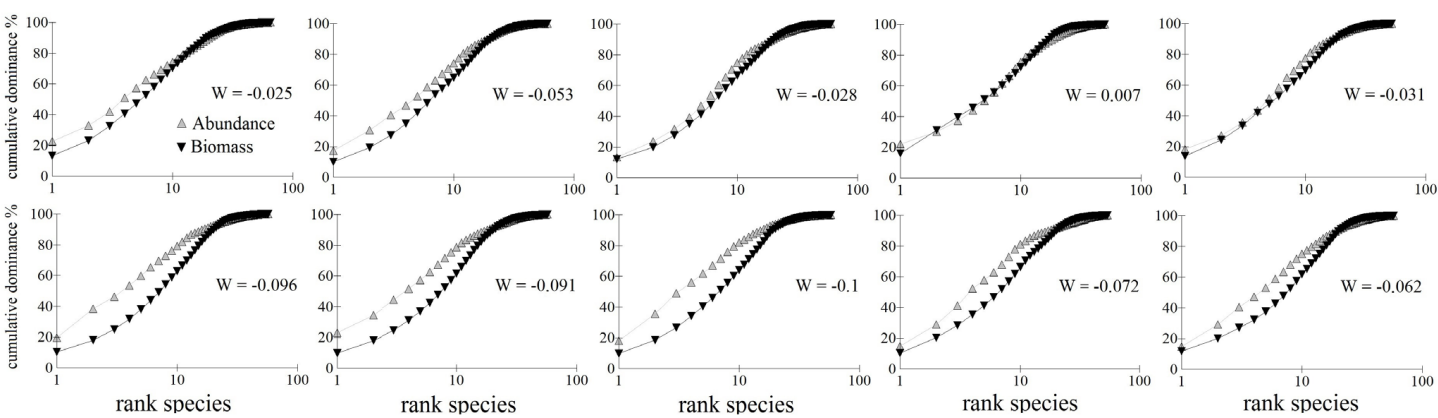

Figure 6. W Statistic and dominance curve for species "ABC plot" based on the number of individuals in the total biomass of fish caught annually at the Itá reservoir from 2001-2010. 


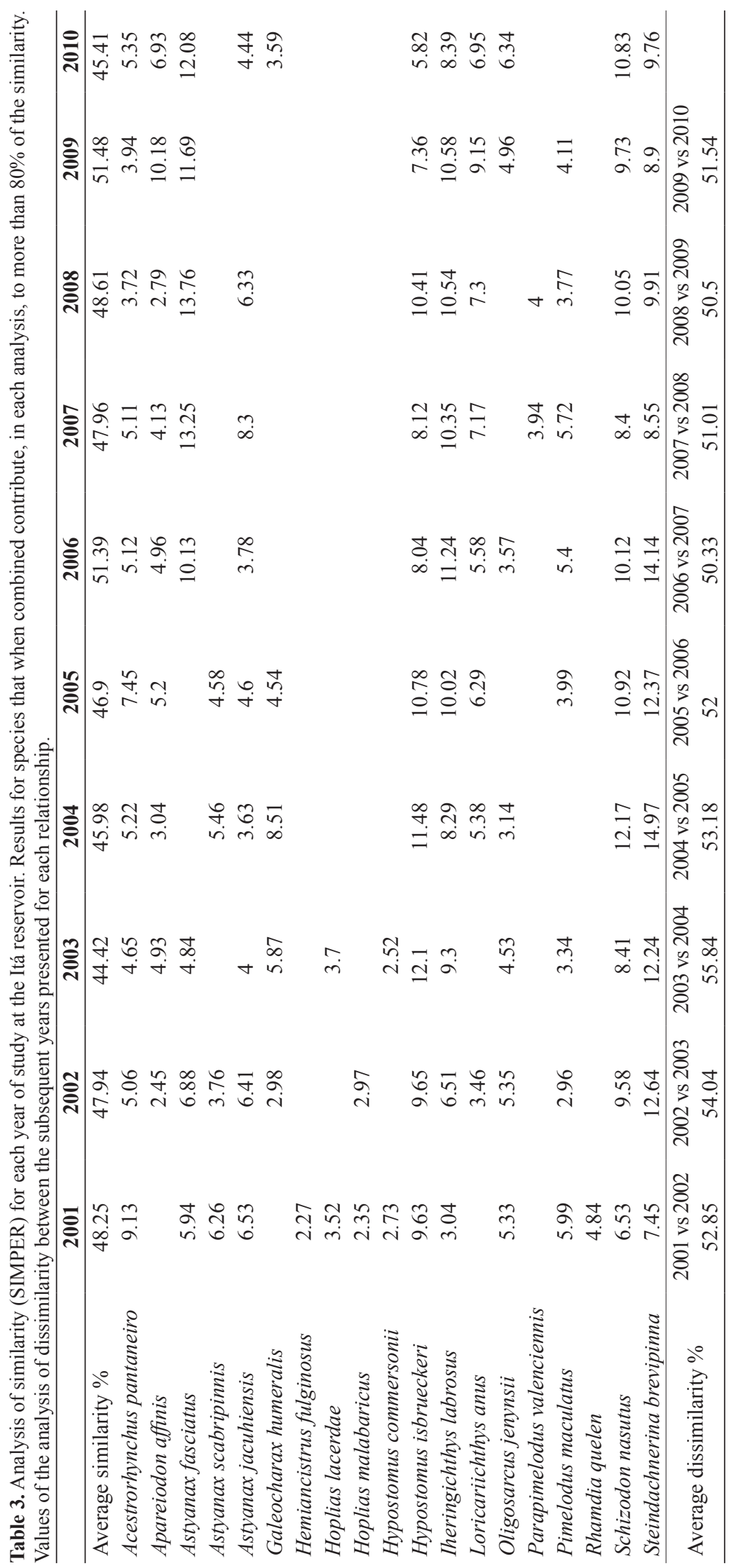


the jundiá Rhamdia quelen, two species that are important in regional fishing (Schork et al., 2013) and that appear to be efficiently completing their lateral reproductive migrations, using tributary rivers to spawn (Zaniboni-Filho and Schulz, 2003).

According to Lemes and Garutti (2002), the constancy of occurrence reflects the biological ability that the species has in exploring the environmental resources available at a given time in the biotope. In this study, it was clear that one of these abilities is to be able to efficiently use the environments provided by the reservoir for reproduction. Fish that conduct long reproductive migrations require a greater number of habitats to complete their life cycle, and for this reason, the dams are obstacles that impede access to certain areas and strongly affect the abundance of their populations (Agostinho et al., 2007).

This is exemplified by the reduced numeric abundance observed of dourado S. brasiliensis and L. obtusidens. Only seven individuals of dourado were captured in the year immediately after the closing of the reservoir, and the species was even more scarce in the catches in the following years, while the piava was only present in catches up to 2007. Meanwhile, the piracanjuba B. orbignyanus was only captured after 2006. Present in the List of Brazilian Fauna Threatened with Extinction, and with its absence reported in the region for approximately twenty-five years (Bertoletti and Lucena, 1989; Beux and Zaniboni-Filho, 2008), this species was the target of an experimental release in 2004. In this year, approximately 3,000 juveniles were released by the staff of the Laboratory of Biology and Cultivation of Fresh Water Fish of the Federal University at Santa Catarina (LAPAD/UFSC), which was possibly related to the catches in this study and raises for discussion the use of stocking techniques as mitigatory and or compensatory measures in the installation of reservoirs.

In turn, the curimba $P$. lineatus stands out as a large migrator with the most expressive catches over the ten years of the study. Although classified as accidental and also vulnerable to the limitations caused by the loss of connectivity of the pristine fluvial environment, the species appears to be able to find minimal conditions to complete its life cycle within the reservoir. For the four species of large migrators caught, in addition to the conditions imposed by the dam, the pressure caused by fishing also appears to be a factor that strongly affects the abundance of their populations (Schork et al., 2013) and should also be considered.

In contrast with the low representation of the large migrators found here, the Itá reservoir had a dominance of small and medium size fish species, classified as sedentary or short-distance migrators, represented above all by birús, lambaris, canivetes, and cascudos. This result concurs with the trend normally found in reservoirs, where species that have less needs to complete their lifecycle are more capable of maintaining their populations, and for this reason, come to dominate the fish assemblage over time (Berkamp et al., 2000). In the same sense, in a study encompassing 75 Brazilian reservoirs, Agostinho et al.
(2007) observed that only 5\% of the reservoirs studied had more than three migratory species among the most abundant fish.

According to Fernando and Holcik (1991), the ichthyofauna that colonizes a reservoir is determined by the existence of species pre-adapted to the lacustrine way of life in the rivers that form the reservoir. This pattern is also observed in the formation of the Itá reservoir, where species already related to the Upper Uruguay River region (Zaniboni-Filho et al., 2008; Zaniboni-Filho et al., 2004; Bertoletti and Lucena, 1989; Godoy, 1987) that have opportunist characteristics were those that had greater success in approval of the new habitats created.

Among them, the most representative was the S. brevipinna, a species typical to the Upper Uruguay River (Zaniboni-Filho and Schulz, 2003) and that was already abundant in the region even before construction of the Itá hydroelectric power plant (Zaniboni-Filho et al., 2008). With efficient reproductive strategies and high alimentary plasticity (Hirt et al., 2011; Vidotto-Magnoni and Carvalho, 2009; Teixeira and Bennemann, 2007; Santos et al., 2004; Luz-Agostinho et al., 2006; Masdeu et al., 2011) A. fasciatus, A. affinis and I. labrosus were also abundant in the Itá reservoir, demonstrating good adaptability to the new environments formed.

From a reproductive perspective, the dominance of species with external fertilization, rapid development and that conduct short or no migratory movements was in keeping with the work of Reynalte-Tataje et al. (2008b) in the Itá reservoir. Other efficient reproductive tactics in the environment studied include the production of numerous small eggs, and low time required for embryogenesis and eclosion, as observed in the representative species of the genre Astyanax and Apareidon (Reynalte-Tataje et al. 2008a).

With different strategies, two species of cascudos stand out, L. anus and H. isbrueckeri. Although they have more complex reproductive tactics, like the production of large and adhesive eggs and parental care (Vazzoler, 1996), these species are among those most caught in the reservoir. For L. anus, the omnivorous iliophagous diet (Albrecht and Silveira, 2001) and a preference for muddy bottoms found in the new lentic environments must have favored its growing relative participation over the years. In addition, L. anus has a distinct type of parental care-carrying eggs in buccal structures - a strategy reported to be efficient for facing the variations in limnological conditions and the level of water in the reservoir (Moodie and Power, 1982), thus avoiding the competition for locations for construction of nests and the eventual exposure of eggs to the air.

A recurring pattern in various reservoirs, the increased population of forager species also leads to the development of piscivore species (Agostinho et al., 2007; Novakowski et al., 2007; Loureiro-Crippa and Hahn, 2006). This fact was previously reported by Zaniboni-Filho et al. (2008) for Galeocharax humeralis, H. malabaricus and mainly for A. pantaneiro, all of which increased in their relative participation in the catch after formation of the Itá lake. This study also found an importance of piscivore fish, with 
$H$. malabaricus and $A$. pantaneiro combined, the second and third largest catches respectively in terms of biomass. The capacity of both to adapt their feeding according to the most abundant prey in the reservoirs (Cantanhede et al., 2008; Pompeu and Godinho, 2001; Novakowski et al., 2007), certainly favored the maintenance of these species under different conditions. Added to the adaptive qualities of the A. pantaneiro, portioned spawning with relatively high fertilization and an absence of parental care (Meurer and Zaniboni-Filho, 2012).

Another process strongly influenced by the formation of reservoirs and that deserves attention in the study of the Itá UHE is the development of aquatic macrophytes (Thomaz et al., 1999; Pelicice et al., 2008; Hermes-Silva and Zaniboni-Filho, 2012). Among the main effects of the presence of macrophytes is the supply of abundant food for herbivorous species, such as $S$. nasutus (Andrade and Braga, 2005), a fish that totaled the highest biomass captured. The species success in colonization of the reservoir should also be related to other ecological adaptations, such as portioned spawning and the absence of parental care (Reynalte-Tataje and Zaniboni-Filho, 2008; Vazzoler and Menezes, 1992).

In relation to the piranhas, contrary to that reported by traditional fishermen, who perceived an increased abundance of piranhas after the formation of the Itá reservoir (Schork et al., 2013), the relative participation in the number of $S$. maculatus and $P$. nattereri remained constant over the ten years of the study. It is possible that this difference is related to the different selectivity of the fishing gear and different locations used by the artisanal fishermen.

The k-dominance curves of the numeric abundance and biomass, corroborated by the $\mathrm{W}$ values, indicate a fish community that was moderately disturbed during the period of study. The proximity of the curves demonstrate the representation of the small and medium species not only numerically, but also in terms of biomass, and point to a discrete imbalance of the environment. This reflection of an ichthyofauna dominated by opportunist species, in which small characids, curimatids, and loricariids alternate as the most representative, with low abundance of large migratory species.

\section{Acknowledgements}

The authors acknowledge CAPES, Tractebel Energia, and Consórcio Itá for financial support; Samara Hermes-Silva for helping us with relevant suggestions.

\section{References}

AGOSTINHO, A.A., GOMES, L.C. and PELICICE, F.M., 2007. Ecologia e manejo de recursos pesqueiros em reservatórios do Brasil. Maringá: Eduem. 501 p.

AGOSTINHO, A.A., GOMES, L.C., SUZUKI, H.I. and JÚLIOJUNIOR, H.F., 2003. Migratory fishes of the Upper Paraná River Basin, Brazil. In: J. CAROLSFELD, B. HARVEY, C. E.
ROSS and A. BAER, eds. Migratory fishes of South America: biology, fisheries and conservation status. Ottawa: The World Bank, pp. 19-98.

AGOSTINHO, A.A., MIRANDA, L.E., BINI, L.M., GOMES, L.C., THOMAZ, S.M. and SUZUKI, H.I., 1999. Patterns of colonization in Neotropical Reservoirs, and prognoses on aging. In: J. G. TUNDISI and M. STRAUKRABA, eds. Theoretical reservoir ecology and its applications. São Carlos: IIE, pp. 227-267.

AGOSTINHO, A.A., PELICICE, F.M. and GOMES, L.C., 2008. Dams and the fish fauna of the Neotropical region: impacts and management related to diversity and fisheries. Brazilian Journal of Biology $=$ Revista Brasileira de Biologia, vol. 68, no. 4, (suppl.), pp. 1119-1132. PMid:19197482. http://dx.doi.org/10.1590/S151969842008000500019 .

ALBRECHT, M.P. and SILVEIRA, C.M., 2001. Alimentação de Loricariichthys anus (Teleostei; Loricariidae) nas lagoas Marcelino e Peixoto, Planície Costeira do Rio Grande do Sul. Acta Limnologica Brasiliensia, vol. 13, no. 1, pp. 79-85.

ANDRADE, P.M. and BRAGA, F.M.S., 2005. Diet and feeding of fish from Grande River, located below the Volta Grande reservoir, MG-SP. Brazilian Journal of Biology = Revista Brasileira de Biologia, vol. 65, no. 3, pp. 377-385. PMid:16341415. http:// dx.doi.org/10.1590/S1519-69842005000300002.

ARAÚJO, F.G., SANTOS, A.B.I. and ALBIERI, R.J., 2013. Assessing fish assemblages similarity above and below a dam in a Neotropical reservoir with partial blockage. Brazilian Journal of Biology $=$ Revista Brasileira de Biologia, vol. 73, no. 4, pp. 727-736. PMid:24789387. http://dx.doi.org/10.1590/S151969842013000400007 .

BAXTER, R.M., 1977. Environmental effects of dams and impoundments. Annual Review of Ecology and Systematics, vol. 8, no. 1, pp. 255-283. http://dx.doi.org/10.1146/annurev. es.08.110177.001351.

BERKAMP, G., MCCARTNEY, M., DUGAN, P., MCNEELY, J. and ACREMAN, M., 2000. Dams, ecosystem functions and environmental restoration. Cape Town: World Commission on Dams. 187 p.

BERTOLETTI, J.J. and LUCENA, C.A.S., 1989. Ictiofauna da área de influência das UHEs de Itá e Machadinho. Relatório Final. Florianópolis: Puc/Cnec/Eletrosul. 80 p.

BEUX, L.F. and ZANIBONI-FILHO, E., 2008. Produção pesqueira do reservatório de Itá, Alto Rio Uruguai. In: E. ZANIBONI-FILHO and A. P. O. NUÑER, eds. Reservatório de Itá: estudos ambientais, desenvolvimento de tecnologias de cultivo e conservação da ictiofauna. Florianópolis: UFSC, pp. 87-108.

BRASIL. Ministério de Minas e Energia, 2015. Boletim mensal de monitoramento do sistema elétrico brasileiro: agosto-2015. Brasilia: MME. 41 p.

CANTANHEDE, G., HAHN, N.S., FUGI, R. and GUBIANI, E.A., 2008. Alterations on piscivorous diet following change in abundance of prey after impoundment in a Neotropical river. Neotropical Ichthyology, vol. 6, no. 4, pp. 631-636. http://dx.doi. org/10.1590/S1679-62252008000400011.

CLARKE, K. and GORLEY, R., 2001. PRIMER v5: user manual. Plymouth: Primer-E. 91 p.

CLARKE, K.R. and WARWICK, R.M., 2001. Change in marine communities: an approach to statistical analysis and interpretation. 2nd ed. Plymouth: Primer-E. 177 p. 
CLARKE, K.R., 1990. Comparisons of dominance curves. Journal of Experimental Marine Biology and Ecology, vol. 138, no. 1, pp. 143-157. http://dx.doi.org/10.1016/0022-0981(90)90181-B.

CODY, M.L., 1996. Introduction to long-term community ecological studies. In: M. L. CODY and J. A. SMALLWOOD, eds. Long-term studies of vertebrate communities. San Diego: Academic Press, pp. 1-15.

DAJOZ, R., 1973. Ecologia geral. São Paulo: Vozes. 471 p.

ELLIOTT, J.M., 1990. The need for long-term investigations in ecology and the contribution of the Freshwater Biological Association. Freshwater Biology, vol. 23, no. 1, pp. 1-5. http:// dx.doi.org/10.1111/j.1365-2427.1990.tb00250.x.

FERNANDO, C.H. and HOLCIK, J., 1991. Fish in reservoirs. Internationale Revue der Gesamten Hydrobiologie, vol. 76, no. 2, pp. 149-167. http://dx.doi.org/10.1002/iroh.19910760202.

GODOY, M.P., 1987. Peixes do estado de Santa Catarina. Florianópolis: UFSC/Eletrosul/FURB. 571 p.

HERMES-SILVA, S. and ZANIBONI-FILHO, E., 2012. Structure of the litoral fish assemblage in an impounded tributary: the effects of macrophytes presence (subtropical region, Brazil). Brazilian Journal of Biology $=$ Revista Brasileira de Biologia, vol. 72, no. 3, pp. 489-495. PMid:22990819. http://dx.doi.org/10.1590/ S1519-69842012000300011.

HIRT, L.M., ARAYA, P.R. and FLORES, S.A., 2011. Population structure, reproductive biology and feeding of Astyanax fasciatus (Cuvier, 1819) in an Upper Paraná River tributary, Misiones Argentina. Acta Limnologica Brasiliensia, vol. 23, no. 1, pp. 1-12. http://dx.doi.org/10.4322/actalb.2011.013.

JORGENSEN, S., TUNDISI, J.G. and TUNDISI, T.M., 2013. Handbook of inland aquatic ecosystem management. Boca Raton: CRC Press. 422 p.

KREBS, C.J., 1998. Ecological methodology. New York: Addison Wesley. $624 \mathrm{p}$.

LEMES, E.M. and GARUTTI, V., 2002. Ecologia da ictiofauna de um córrego de cabeceira da bacia do Alto rio Paraná, Brasil. Iheringia. Série Zoologia, vol. 92, no. 3, pp. 69-78.

LOUREIRO-CRIPPA, V.E. and HAHN, N., 2006. Use of food resources by the fish fauna of small reservoir (rio Jordão, Brazil) before and shortly after its filling. Neotropical Ichthyology, vol. 4, no. 3, pp. 357-362. http://dx.doi.org/10.1590/S167962252006000300007

LUZ-AGOSTINHO, K.D.G., BINI, L.M., FUGI, R., AGOSTINHO, A.A. and JÚLIO JUNIOR, H.F., 2006. Food spectrum and trophic structure of the ichthyofauna of Corumbá reservoir, Paraná river Basin, Brazil. Neotropical Ichthyology, vol. 4, no. 1, pp. 61-68. http://dx.doi.org/10.1590/S1679-62252006000100005.

MASDEU, M., MELLO, F.T., LOUREIRO, M. and ARIM, M., 2011. Feeding habits and morphometry of Iheringichthys labrosus (Lütken, 1874) in the Uruguay River (Uruguay). Neotropical Ichthyology, vol. 9, no. 3, pp. 657-664. http://dx.doi.org/10.1590/ S1679-62252011005000034.

MEURER, S. and ZANIBONI-FILHO, E., 2012. Reproductive and feeding biolgy of Acestrorhynchus pantaneiro Menezes, 1992 (Osteichthyes: Acestrorhynchidae) in areas under the influence of dams in the upper Uruguay River, Brazil. Neotropical Ichthyology, vol. 10 , no. 1 , pp. 159-166. http://dx.doi.org/10.1590/S167962252012000100015 .
MONTENEGRO, A.K.A., TORELLI, J.E.R., CRISPIM, M.C., HERNÁNDEZ, M.I.M. and MEDEIROS, A.M.A., 2012. Ichthyofauna diversity of Taperoá II reservoir, semi-arid region of Paraíba, Brazil. Brazilian Journal of Biology $=$ Revista Brasileira de Biologia, vol. 72, no. 1, pp. 113-120. PMid:22437391.

MOODIE, E.E. and POWER, M., 1982. The reproductive biology of an armoured catfish, Loricaria uracantha, from Central America. Environmental Biology of Fishes, vol. 7, no. 1, pp. 143-148.

NOVAES, J.L.C., MOREIRA, S.I.L., FREIRE, C.E.C., SOUSA, M.M.O. and COSTA, R.S., 2014. Fish assemblage in a semi-arid Neotropical reservoir: composition, structure and patterns of diversity and abundance. Brazilian Journal of Biology $=$ Revista Brasileira de Biologia, vol. 74, no. 2, pp. 290-301. PMid:25166313. http://dx.doi.org/10.1590/1519-6984.14712.

NOVAKOWSKI, G.C., HAHN, N.S. and FUGI, R., 2007. Alimentação de peixes piscívoros antes e após a formação do reservatório de Salto Caxias, Paraná, Brasil. Biota Neotropica, vol. 7, no. 2, pp. 149-154. http://dx.doi.org/10.1590/S167606032007000200017

PELICICE, F.M., THOMAZ, S.M. and AGOSTINHO, A.A., 2008. Simple relationships to predict attributes of fish assemblages in patches of submerged macrophytes. Neotropical Ichthyology, vol. 6 , no. 4 , pp. 543-550. http://dx.doi.org/10.1590/S167962252008000400001

PETESSE, M.L. and PETRERE-JUNIOR, M., 2012. Tendency towards homogenization in fish assemblages in the cascade reservoir system of the Tiête river basin, Brazil. Ecological Engineering, vol. 48, pp. 109-116. http://dx.doi.org/10.1016/j. ecoleng.2011.06.033

PIELOU, E.C., 1966. Species-diversity and pattern-diversity in the study of ecological succession. Journal of Theoretical Biology, vol. 10, no. 2, pp. 370-383. PMid:5964400. http://dx.doi. org/10.1016/0022-5193(66)90133-0.

POMPEU, P.S. and GODINHO, A.L., 2001. Mudanças na dieta da traíra Hoplias malabaricus (Bloch) (Erythrinidae, Characiformes) em lagoas da bacia do rio Doce devido à introdução de peixes piscívoros. Revista Brasileira de Zoologia, vol. 18, no. 4, pp. 1219-1225. http://dx.doi.org/10.1590/S0101-81752001000400016.

REYNALTE-TATAJE, D.A. and ZANIBONI-FILHO, E., 2008. Biologia e identificação de ovos e larvas de peixes do alto rio Uruguai. In: E. ZANIBONI-FILHO and A. P. O. NUÑER, eds. Reservatório de Itá: Estudos ambientais, desenvolvimento de tecnologias de cultivo e conservação da ictiofauna. Florianópolis: UFSC, pp. 229-255.

REYNALTE-TATAJE, D.A., HERMES-SILVA, S., CARVALHOSILVA, M.M., ABBUD, F.M., CORREA, R.N. and ZANIBONIFILHO, E., 2008a. Distribuição de ovos e larvas de peixes na área de influência do reservatório de Itá (Alto Rio Uruguai). In: E. ZANIBONI-FILHO and A. P. O. NUÑER, eds. Reservatório de Itá: estudos ambientais, desenvolvimento de tecnologias de cultivo e conservação da ictiofauna. Florianópolis: UFSC, pp. 109-158.

REYNALTE-TATAJE, D.A., HERMES-SILVA, S., SILVA, P.A., BIALETZKI, A. and ZANIBONI-FILHO, E., 2008b. Locais de crescimento de larvas de peixes na região do Alto Rio Uruguai (Brasil). In: E. ZANIBONI-FILHO and A. P. O. NUÑER, eds. Reservatório de Itá: estudos ambientais, desenvolvimento de tecnologias de cultivo e conservação da ictiofauna. Florianópolis: UFSC, pp. 159-194.

RIBEIRO-FILHO, R.A., PETRERE-JUNIOR, M., BENASSI, S.F. and PEREIRA, J.M.A., 2011. Itaipu Reservoir limnology: 
eutrophication degree and the horizontal distribution of its limnological variables. Brazilian Journal of Biology $=$ Revista Brasileira de Biologia, vol. 71, no. 4, pp. 889-902. http://dx.doi. org/10.1590/S1519-69842011000500010.

SANCHES, B.O., HUGHES, R.M., MACEDO, D.R., CALLISTO, M. and SANTOS, G.B., 2016. Spatial variations in fish assemblage structure in a southeastern Brazilian reservoir. Brazilian Journal of Biology = Revista Brasileira de Biologia, vol. 76, no. 1, pp. 185193. PMid:26909635. http://dx.doi.org/10.1590/1519-6984.16614.

SANTOS, J.E., BAZZOLI, N., RIZZO, E. and SANTOS, G.B., 2004. Reproduction of the catfish Iheringichthys labrosus (Lütken) (Pisces, Siluriformes) in Furnas reservoir, Minas Gerais, Brazil. Revista Brasileira de Zoologia, vol. 21, no. 2, pp. 193-200. http:// dx.doi.org/10.1590/S0101-81752004000200006.

SCHORK, G., HERMES-SILVA, S. and ZANIBONI-FILHO, E., 2013. Analysis of fishing activity in the Itá reservoir, Upper Uruguay River, in the period 2004-2009. Brazilian Journal of Biology $=$ Revista Brasileira de Biologia, vol. 73, no. 3, pp. 559-571. PMid:24212697. http://dx.doi.org/10.1590/S151969842013000300014.

SIMPSON, E.H., 1949. Measurement of diversity. Nature, vol. 163, no. 4148, pp. 668. http://dx.doi.org/10.1038/163688a0.

SOUZA-FILHO, E.E., 2009. Evaluation of the upper Paraná river discharge controlled by reservoirs. Brazilian Journal of Biology = Revista Brasileira de Biologia, vol. 69, no. 2, (suppl.), pp. 707-716. PMid:19738976. http://dx.doi.org/10.1590/S151969842009000300024 .

TEIXEIRA, I. and BENNEMANN, S.T., 2007. Ecomorfologia refletindo a dieta dos peixes em um reservatório no sul do Brasil. Biota Neotropica, vol. 7, no. 2, pp. 67-76. http://dx.doi.org/10.1590/ S1676-06032007000200007.

THOMAZ, S.M., BINI, L.M., SOUZA, M.C., KITA, K.K. and CAMARGO, A.F.M., 1999. Aquatic macrophytes of itaipu reservoir, Brazil: survey of species and ecological considerations. Brazilian Archives of Biology and Technology, vol. 42, no. 1, pp. 15-22.

TUNDISI, J.G. and STRASKRABA, M., 1999. Theoretical reservoir ecology and its applications. São Carlos: IIE. 585 p.
VANNOTE, R.L., MINSHALL, J.V., CUMMINS, K.W., SEDELL, J.R. and CUSHING, C.E., 1980. The river continuum concept. Canadian Journal of Fisheries and Aquatic Sciences, vol. 37, no. 1, pp. 130-137. http://dx.doi.org/10.1139/f80-017.

VAZZOLER, A.E.A.M. and MENEZES, N.A., 1992. Síntese de conhecimento sobre o comportamento reprodutivo dos Characiformes da América do Sul (Teleostei: Characiformes). Revista Brasileira de Biologia, vol. 52, no. 4, pp. 627-640.

VAZZOLER, A.E.A.M., 1996. Biologia da reprodução de peixes teleósteos: teoria e prática. Maringá: EDUEM. 169 p.

VAZZOLER, A.E.A.M., SUZUKI, H.I., MARQUES, E.E. and LIZAMA, M.A.P., 1997. Primeira maturação gonadal, períodos e áreas de reprodução. In: A.E.A.M. VAZZOLER, A.A. AGOSTINHO and N.S. HAHN. eds. Planície de inundação do Alto Rio Paraná. Maringá: EDUEM, pp. 249-265.

VIDOTTO-MAGNONI, A.P. and CARVALHO, E.D., 2009. Aquatic insect as the main food resource of fish the community in Neotropical reservoir. Neotropical Ichthyology, vol. 7, no. 4, pp. 701-708. http://dx.doi.org/10.1590/S1679-62252009000400020.

WARWICK, R.M., 1986. A new method for detecting pollution effects on marine macrobenthic communities. Marine Biology, vol. 92, no. 4, pp. 557-562. http://dx.doi.org/10.1007/BF00392515.

ZANIBONI-FILHO, E. and SCHULZ, U.H., 2003. Migratory fishes of the Uruguay river. In: J. CARLOSFELD, B. HARVEY, A. BAER and C. ROSS, eds. Migratory fishes of the South América: biology, social importance and conservation status. Victoria: World Fisheries Trust, pp. 135-168.

ZANIBONI-FILHO, E., MEURER, S., SHIBATTA, O.A. and NUÑER, A.P.O., 2004. Catálogo ilustrado de peixes do alto rio Uruguai. Florianópolis: UFSC/Tractebel Energia. 128 p.

ZANIBONI-FILHO, E., NUÑER, A.P.O., REYNATE-TATAJE, D.A., HERMES-SILVA, S. and MEURER, S., 2008. Alterações espaciais e temporais da estrutura da comunidade de peixes em decorrência da implantação do reservatório de Itá (Alto Rio Uruguai). In: E. ZANIBONI-FILHO and A.P.O. NUÑER, eds. Reservatório de Itá: Estudos ambientais, desenvolvimento de tecnologias de cultivo e conservação da ictiofauna. Florianópolis: UFSC, pp. 21-48. 